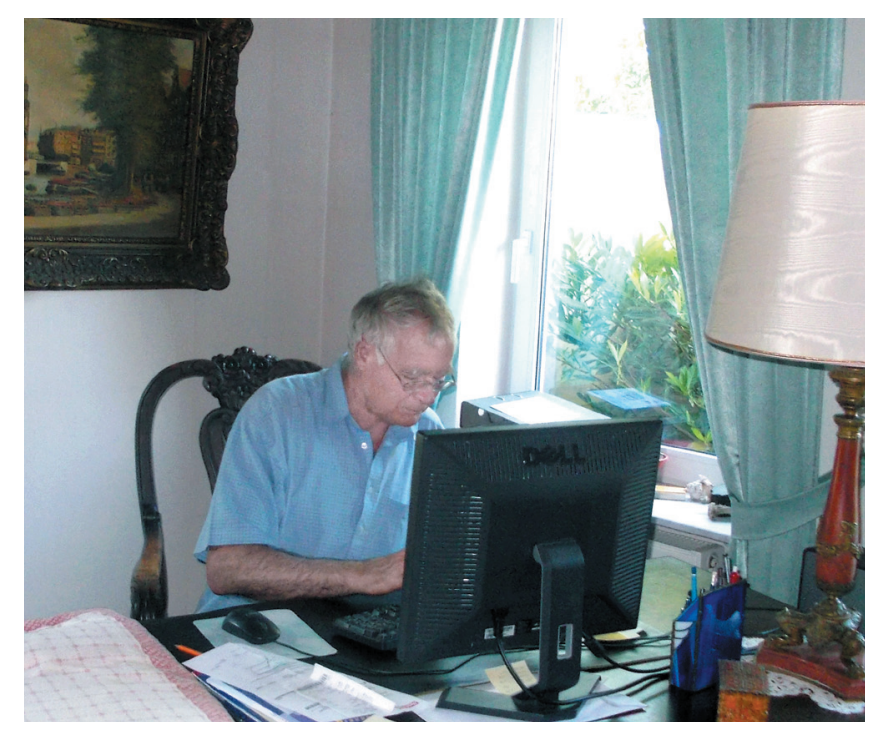

Professor Heinrich Homborg, known to friends and colleagues as "Heiner", passed suddenly away on May $14^{\text {th }} 2020$. An outstanding German phthalocyanine chemist, he has made a substantial contribution to the coordination, structural chemistry and spectroscopy of this class of dyes and for many years was the member of the International Advisory Board of the journal "Macroheterocycles".

Heiner was born on September $10^{\text {th }} 1941$ and received his $\mathrm{PhD}$ degree in 1973 in the University of Saarbrücken (Germany) with a thesis entitled "Stereospecific preparation and spectrophotometric characterization of new mixed halogeno complexes of osmium(IV)". Later he moved to Christian-Albrechts University (CAU) in Kiel following his teacher and colleague Professor Wilhelm Preetz who received there Chair of Inorganic Chemistry. In 1984 Heinrich Homborg completed his habilitation with the thesis "Preparation and characterization of new phthalocyanines of $\mathrm{Al}, \mathrm{Co}, \mathrm{Fe}, \mathrm{Li}, \mathrm{Mg}, \mathrm{Zn}$ ". Later he became Professor and in 1992 was appointed Academic Director of the Institute of Inorganic Chemistry of CAU.

Professor Heiner Homborg has started his scientific carrier with the study of the halogen complexes of the noble metals, especially osmium and iridium, ${ }^{[1]}$ and applied the resonance Raman spectroscopy for investigation of their electronic and vibration spectra. ${ }^{[2]}$ In 1978 he has published his first works on phthalocyanine chemistry $^{[3,4]}$ in which properties of lithium phthalocyanine were studied. Since then chemistry of phthalocyanine became his main research field and he has published more than 100 papers on synthesis, spectral characterization and structure of phthalocyanine complexes with different metal ions. Most of his works were published in German language in his favourite journal "Zeitschrift

\section{In Memoriam - Professor Dr. Heinrich Homborg}

fur Anorganische und Allgemeine Chemie". Especially essential contribution was made in the study of complexes with $\mathrm{Li}, \mathrm{Fe}$, noble metals ( $\mathrm{Ru}, \mathrm{Os}, \mathrm{Rh}, \mathrm{Ir}$ ), $\mathrm{Cr}, \mathrm{Mo}, \mathrm{Mn}$, Re, lanthanides, and In. It was shown in his works that phthalocyanine macrocycle can be easily oxidized with formation of complexes containing stable macrocyclic $\pi$-cation radicals. ${ }^{[4,5]}$ Different kinds of bisphthalocyanine complexes were prepared and characterized - sandwich type $\mathrm{Pc}_{2} \mathrm{M}$ in the case of lanthanides, ${ }^{[6]} \mathrm{Sc}, \mathrm{Y}, \mathrm{In}, \mathrm{Bi}$, metal-metal bonded $(\mathrm{PcM})_{2}$ in the case of Mo, Rh and $\mathrm{Ir}^{\left[{ }^{[7]}\right.}$ and single atom $\mu$-bridged complexes - $\mu$-oxo dimers

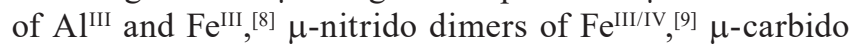
dimers of $\mathrm{Fe}^{\mathrm{IV}}, \mathrm{Ru}^{\mathrm{IV}} \cdot{ }^{[10]}$ Complexes of phthalocyanine analogues - subphthalocyanines, ${ }^{[11]}$ naphthalocyanines, azaporphyrins ${ }^{[12]}$ and porphyrazines ${ }^{[13]}$ were also studied. Application of the resonance Raman spectroscopy for characterization of phthalocyanine complexes was quite useful for the proper assignment of their vibration spectra and electronic transitions observed in the visible and near IR regions. ${ }^{[14]}$ Professor Heiner Homborg has suggested to use bulky cations such as bis(triphenylphosphin)iminium $\left(\mathrm{pnp}^{+}\right)^{[15]}$ and tetrabulylammonium $\left(\mathrm{tba}^{+}\right)^{[16]}$ for isolation of the anionic phthalocyaninatometallate complexes. This approach allowed obtaining high quality single crystals and more that 130 metal phthalocyanine complexes were structurally characterized by X-ray diffraction analysis.

Under supervision of Professor Heiner Homborg more than $20 \mathrm{PhD}$ students have successfully accomplished their doctoral thesis in the field of phthalocyanine chemistry. His lab in CAU was also very welcome for foreign post-doc and visiting scientists and I was very happy to have a chance to stay there in 1992-94 as a postdoc and several times thereafter. We have discussed not 


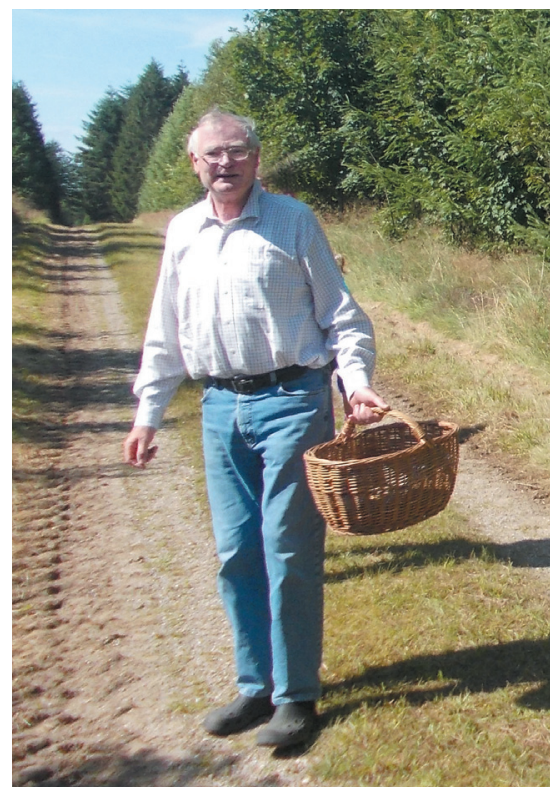

\section{References}

1. Preetz W., Homborg H. Darstellung von chloro-jodoosmaten(IV) einschließlich der cis-trans-isomeren. J. Inorg. Nucl. Chem. 1970, 32, 1979-1987. DOI: 10.1016/00221902(70)80607-8.

2. Homborg H., Preetz W. Tieftemperatur-Raman-Messungen an rotierenden festen Proben. Spectrochim. Acta A 1976, 32, 709-716. DOI: 10.1016/0584-8539(76)80138-9.

3. Homborg H., Kalz W. Preparation and Characterisation of Tetraalkylammonium-lithium-phthalocyanines Z. Naturforschung B. 1978, B33, 968-975. DOI: 10.1515/znb-1978-0903.

4. Homborg H., Kalz W. The Oxidation of phthalocyanines: preparation and Characterization of Lithiumphthalocyanine(1-) Z. Naturforschung B 1978, B33, 1067-1071. DOI: 10.1515/znb-1978-1002.

5. Homborg H. Darstellung und Charakterisierung von Phthalocyanin $\pi$-Kation-Radikalen von $\mathrm{H}^{+}, \mathrm{Mg}^{2+}$ und $\mathrm{Cu}^{2+}$. Z. anorg. allg. Chem. 1983, 507, 35-50. DOI: 10.1002/zaac.19835071205

6. Haghighi M.S., Homborg H. Spektroskopische Eigenschaften von Di(phthalocyaninato)metallaten(III) der Seltenen Erden Teil 1: Elektronische Absorptionsspektren und Schwingungsspektren. Z. anorg. allg. Chem. 1994, 620, 1278-1284. DOI: 10.1002/zaac.19946200723.

7. Hückstädt H., Homborg H. Dimeric $\operatorname{Ir}^{\text {II }}$ Phthalocyaninates with an Ir-Ir Bond; Crystal Structure of Di(pyridinephthalocyaninato(2-)-iridium(II)). Z. anorg. allg. Chem. 1997, 623, 369-378. DOI: 10.1002/zaac.19976230159

8. Kennedy B.J., Zwack P.R., Murray K.S., Homborg H., Kalz W. ( $\mu$-Oxo)iron(III) Phthalocyanine. Electronic Structure of the Solid Form Obtained from a Dihydroxo-Iron(III) Precursor. Inorg. Chem. 1985, 24, 3302-3305. DOI: 10.1021/ ic00214a041

9. Kennedy B.J., Murray K.S., Homborg H., Kalz W. Iron(IV)Phthalocyanines. Magnetic and Spectral Features of $\mu$-Nitrido-iron-phthalocyanine, $(\mathrm{FePc})_{2} \mathrm{~N}$ and of Some Oxidized Derivatives. Inorg. Chim. Acta 1987, 134, 19-21. DOI: 10.1016/S0020-1693(00)84449-7. only chemistry, but also mankind problems in the rapidly changing world.

During my stay in Kiel I was often a guest in his hospitable house located in the surroundings and remember well excellent French meals prepared by his wife Marie-Claude. Heiner has made everything by himself in his house from renovation and engineering works inside to building of extension. Together with Marie-Claude they have taken care about the garden with vegetables and fruit trees, raised chickens and ducks. This helped him to stay active after the early retirement from the University. In one of his last letters he even wrote "... it would have been better to become an architect or a building contractor". Heiner liked culture and nature. He was fond of paintings and old furniture. Danish forests were his favourite place for gathering of Steinpilze (fungi Porcini).

Heiner's contribution to phthalocyanine chemistry will stay and influence the development of science, but his family and friends will deeply miss him....

\section{Pavel A. Stuzhin Ivanovo State University of Chemistry and Technology E-mail:stuzhin@isuct.ru}

10. Kienast A., Bruhn C., Homborg H. Synthesis, Properties, and Crystal Structure of $\mu$-Carbidodi(pyridinephthalocyaninato(2-)iron(IV)) and -ruthenium(IV). Z. anorg. allg. Chem. 1997, 623, 967-972. DOI: 10.1002/zaac.199762301151.

11. Potz R., Göldner M., Hückstädt H., Cornelissen U., Tutaß A., Homborg H. Synthesis and Structural Characterization of Boron Subphthalocyaninates. Z. anorg. allg. Chem. 2000, 626, 588-596. DOI: 10.1002/(SICI)15213749(200002)626:2<588::AID-ZAAC588>3.0.CO;2-B.

12. Stuzhin P.A., Goeldner M., Homborg H., Semeikin A.S., Migalova I.S., Wolowiec S. Diazaporphyrins: Synthesis, Characterization and X-Ray Crystal Structure of (3,7,13,17-Tetramethyl-2,8,12,18-tetrabutyl-5,15-diazaporphinato)chloroindium(III). Mendeleev Commun. 1999, 9, 134-136. DOI: 10.1070/mc1999v009n04abeh001100.

13. (a) Stuzhin P.A., Homborg H. Iron(II), Ruthenium(II), and Osmium(II) Octaphenyltetraazaporphinates with Axially Coordinated Pyridine: Synthesis and Electronic Absorption Spectra. Russ. J. Coord. Chem. 1997, 23, 623-628 [Koord. Khim. 23, 666-671]; (b) Stuzhin P.A., Migalova I.S., Homborg H. Pentacoordinated Complexes of Octaphenyltetraazaporphine Indium(III) with Monodentate Acidoligands [(X) InOPTAP] (X = F, Cl, Br, SCN, or OCN). Russ. J. Coord. Chem. 2000, 26, 6-11 [Koord. Khim. 2000, 26, 9-14].

14. Sievertsen S., Schlehahn H., Homborg H. Darstellung, Eigenschaften und elektronische Raman-Spektren von Bis(chloro) phthalocyaninatoferrat(III), -ruthenat(III) und -osmat(III). Z. anorg. allg. Chem. 1993, 619, 1064-1072. DOI: 10.1002 zaac.19936190617.

15. Küppers H., Eulert H.-H., Hesse K.-F., Kalz W., Homborg H. Synthesis and Crystal Structure of Di[bis(triphenylphosphine)iminium]-biscyanophthalocyaninatoferrate(II)dichloromethane. Z. Naturforschung B. 1986, B41, 44-47. DOI: 10.1515/znb-1986-0109.

16. Kalz W., Homborg H. Iron(III)phthalocyanines: Preparation and Spectroscopic Characterisation of $\left[\mathrm{Fe}(\mathrm{OR})_{2} \mathrm{Pc}(-2)\right]^{-}$. $Z$. Naturforschung B. 1983, B38, 470-484. DOI: 10.1515/znb1983-0414. 